\title{
СОСТАВ КАЛЬЦИТОВЫХ КАРБОНАТИТОВ КОВДОРСКОГО МАССИВА, КАК ПОТЕНЦИАЛЬНЫХ ПРОМЫШЛЕННЫХ РУД
}

\author{
К. Д. Степанова ${ }^{1}$, С. В. Петров ${ }^{2}$ \\ ${ }^{1}$ Санкт-Петербургский горный университет \\ ${ }^{2}$ Санкт-Петербургский государственный университет
}

Поступила в редакцию 12 февраля 2018 г.

\begin{abstract}
Аннотация: Ковдорский щелочно-ультраосновной массив один из наиболее ярких представителей в семействе аналогичных комплексов Карело-Кольского региона. В настоящем исследовании приведены результаты изучения вещественного состава руд из апатит-карбонатного месторождения в юго-западной части Ковдорского массива, среди которых были выделены основные технологические сорта по содержанию $P_{2} O_{5}$ в мас. \%: бедные $(<1,5)$, рядовые $(1,5-$ 3) и богатые (> 3). Минералого-петрографические исследования проводились с использованием оптических, рентгеновских и электронномикроскопических методов. Подсчитаны относительные процентные содержания минералов, что позволило выделить среди них главные, второстепенные и акиессорные. Определены их химические составы, описаны кристаллические формы, размеры и текстурно-структурные характеристики. Отмечены характерные взаимоотношения главных и второстепенных минералов между собой в изучаемых породах. Выявлено, что все вышеуказанные характеристики минералов являются типичными для месторождения данного типа.

Ключевые слова: Ковдорский массив, апатит-карбонатные руды, кальцитовые карбонатиты, апатит, технологические сорта руд.
\end{abstract}

\section{MATERIAL COMPOSITION OF CALCITE CARBONATITES OF THE KOVDOR MASSIF THAT ARE POTENTIAL INDUSTRIAL ORES}

\begin{abstract}
Kovdor massif of alkaline, ultrabasic and carbonatite rocks is one of the brightest representatives in the family of similar complexes in Karelian-Kola region. This research presents the results of study material composition of ores that are located in the apatite-carbonate deposit at the SouthEastern part of the Kovdor massif. These ores are divided into basic technological classes according to the content of $\mathrm{P}_{2} \mathrm{O}_{5}$ in vol. \%: poor $(<1,5)$, common $(1,5-3)$ and rich (>3). Mineralogical and petrographic studies were carried out using the optical, $x$-ray and electron microscopic methods. We have estimated relative abundances which allowed allocating main, minor and accessory minerals. The chemical composition of minerals has been determined. The crystalline forms of minerals, size of its and their textural and structural features have been described in this study. Accordingly, we have educed that above-named mineral characteristics are representative for deposit of this type.

Key words: Kovdor massif, apatite-carbonate ores, calcite carbonatites, apatite, technological grades of ore.
\end{abstract}

\section{Введение}

Ковдорский массив ультраосновных, щелочных пород и карбонатитов находится на Кольском полуострове и представляет собой сложную многофазную интрузию центрального типа площадью 40,5 км², которая 380 млн. лет тому назад прорвала древние гнейсы и гранито-гнейсы. Массив окружен ореолом фенитизации во вмещающих породах, ширина которого колеблется в широких пределах, местами достигая 3 4 км. [1, 2, 3].

С Ковдорским массивом пространственно и генетически связан ряд месторождений: оливинитовое, комплексное бадделеит-апатит-магнетитовое, флогопитовое и вермикулитовое; в том числе месторождение апатит-карбонатных руд, расположенное в югозападной части массива (рис. 1) [4, 5].

В настоящий момент сырьевую базу горноперерабатывающей промышленности, связанной с массивом, представляет месторождение комплексных бадделеит-апатит-магнетитовых руд, разрабатываемое ОАО «Ковдорский ГОК». За последние несколько лет был разработан проект расширения основного карьера месторождения (рудник Железный), что приведет к понижению дна карьера до глубины в 


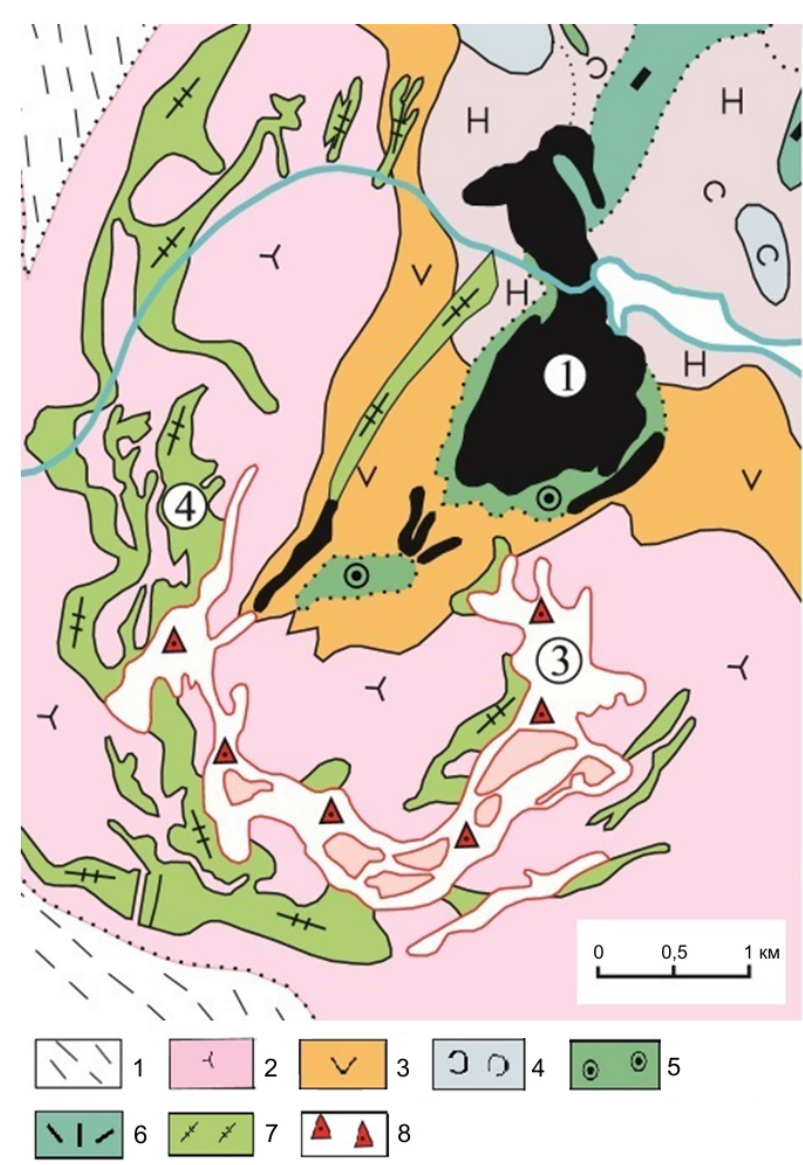

Puc. 1. Геологическая карта Ковдорского массива (югозападная часть) [1]. Месторождения (цифры в кружках): 1 комплексное бадделеит-апатит-магнетитовое; 3 - апатитштаффелитовое; 4 - карбонатитов. Условные обозначения: 1 - архейские гнейсы; 2 - фениты; 3 - йиолиты; 4 - гранатпироксеновые породы; 5 - апатит-форстерит-флогопитовые породы; 6 - флогопит-диопсидовые породы; 7 - кальцитовые карбонатиты с апатитом, флогопитом, магнетитом; 8 апатит-штаффелитовые коры выветривания.

800 метров. Известно, что в зону разноски бортов карьера попадает месторождение апатит-карбонатных руд: кальцитовые карбонатиты и перекрывающие их апатит-штаффелитовые коры выветривания.

Согласно литературным данным, запасы апатиткарбонатных руд могут служить сырьевой базой комплексного горнорудного предприятия по производству апатитового и железного концентратов, а также карбонатного продукта $[6,7,8]$.

Ввиду того, что изучение вещественного состава данных руд не проводилось ранее, в том числе минералов редких металлов, подобные исследования могут быть использованы при рассмотрении перспектив их использования.

\section{Методика исследования}

Для изучения вещественного состава апатиткарбонатных руд были изготовлены 23 петрографических шлифа из материала минералого-технологических проб скважины, пробуренной в пределах месторождения. Из керна скважины были выбраны шесть интервалов, отвечающих основным технологическим сортам руд Ковдорского месторождения, установленным по содержанию $\mathrm{P}_{2} \mathrm{O}_{5}$ в мас. \%: бедные $(<1,5)$, рядовые $(1,5-3)$ и богатые $(>3)$. Исследование препаратов проводилось с использованием поляризационного микроскопа Olympus BX51, оборудованного цифровой камерой SIMAGIS 2P-3C. Для изучения текстурно-структурных характеристик пород применялось ультрафиолетовое облучение с фотофиксацией. Химический состав пород определялся на настольном порошковом дифрактометре Bruker «D2 Phaser» c медным и кобальтовым анодом рентгенофлуоресцентным анализом на базе ресурсного центра СанктПетербургского государственного университета. Микрозондовый анализ минералов в аншлифах осуществлялся микрорентгеноспектральным методом на сканирующем электронном микроскопе Hitachi S$3400 \mathrm{~N}$ на базе ресурсного центра Санкт-Петербургского государственного университета. Относительное содержание минералов оценивалось площадным методом в петрографических шлифах.

\section{Результаты исследования и их обсуждение Богатые апатит-карбонатные руды}

Среди богатых руд преобладают апатиткальцитовые и кальцитовые карбонатиты, главными минералами которых являются кальцит и апатит (табл. 1) Отмечается необычная форма выделения апатита - игольчатые, лейстовые индивиды (рис. 2). Второстепенные минералы представлены флогопитом, форстеритом, магнетитом и пирротином. Отмечается развитие вторичных минералов - серпентина и клиногумита по форстериту, амфиболов по флогопиту, вплоть до полного их замещения (рис. 3).

Текстуры пород: полосчатая, пятнистая и линзовидная. Такие типы текстур обусловлены тем, что промежутки между кристаллами кальцита выполнены зернистыми выделениями апатита, а также скелетнографическими агрегатами рудных минералов (рис. 4). Характерная структура - гипидиоморфнозернистая с элементами пойкилобластовой.

Характерной особенностью химического состава пород является обогащенность стронцием.

Таблица 1

Минеральный состав богатых руд

\begin{tabular}{|l|c|c|c|}
\hline \multirow{2}{*}{ Минерал } & \multicolumn{3}{|c|}{ Содержания минералов, \% } \\
\cline { 2 - 4 } & $\begin{array}{c}\text { шлиф } \\
\text { СК/3b-92,2, } \\
\text { (№ 2.5) }\end{array}$ & $\begin{array}{c}\text { Шличф } \\
\text { (№ 2.7) }\end{array}$ & $\begin{array}{c}\text { шлиф } \\
\text { С25к/1b-31,1 } \\
\text { (№ 2.19) }\end{array}$ \\
\hline Кальцит & 95 & 92 & 87 \\
\hline Апатит & 5 & 5 & 10 \\
\hline Форстерит & - & 1 & - \\
\hline Флогопит & - & 1 & 1 \\
\hline Рудные & - & 1 & 2 \\
\hline Итого: & 100 & 100 & 100 \\
\hline
\end{tabular}



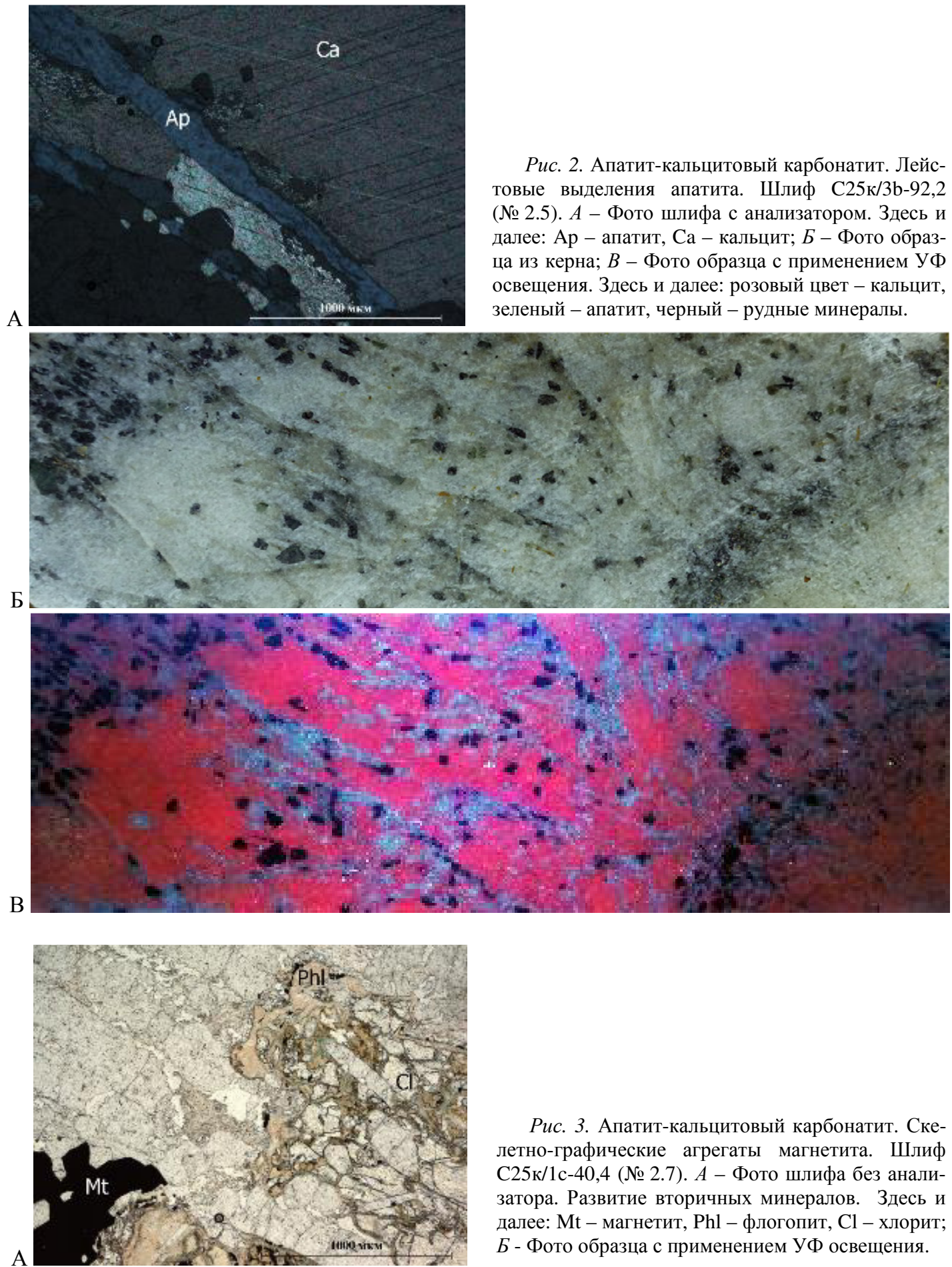

Puc. 3. Апатит-кальцитовый карбонатит. Скелетно-графические агрегаты магнетита. Шлиф С25к/1c-40,4 (№ 2.7). $A$ - Фото шлифа без анализатора. Развитие вторичных минералов. Здесь и далее: $\mathrm{Mt}$ - магнетит, $\mathrm{Phl}$ - флогопит, $\mathrm{Cl}$ - хлорит; $Б$ - Фото образца с применением УФ освещения.

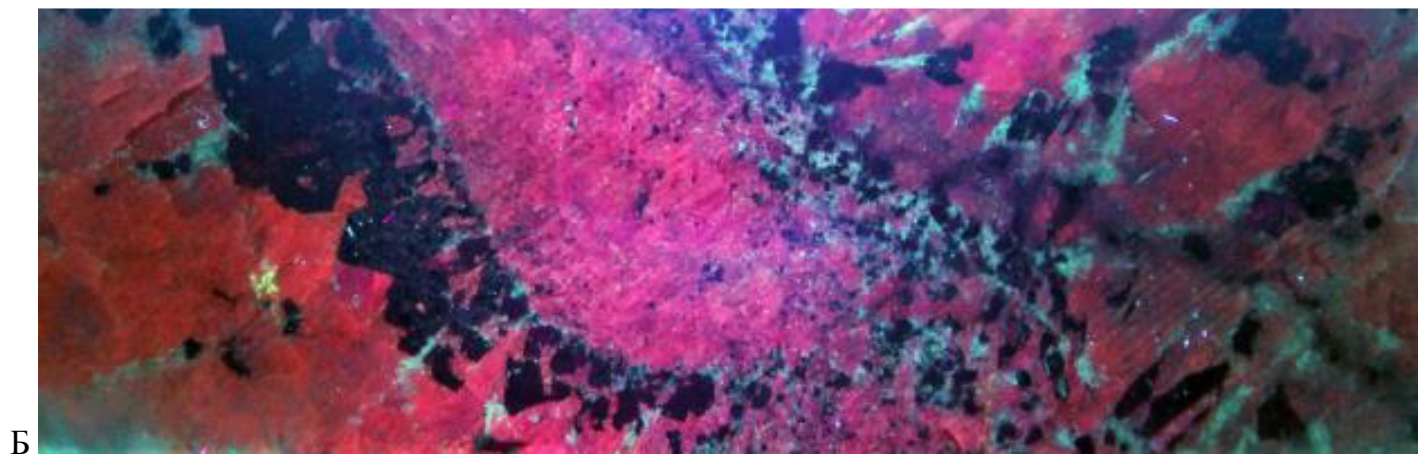



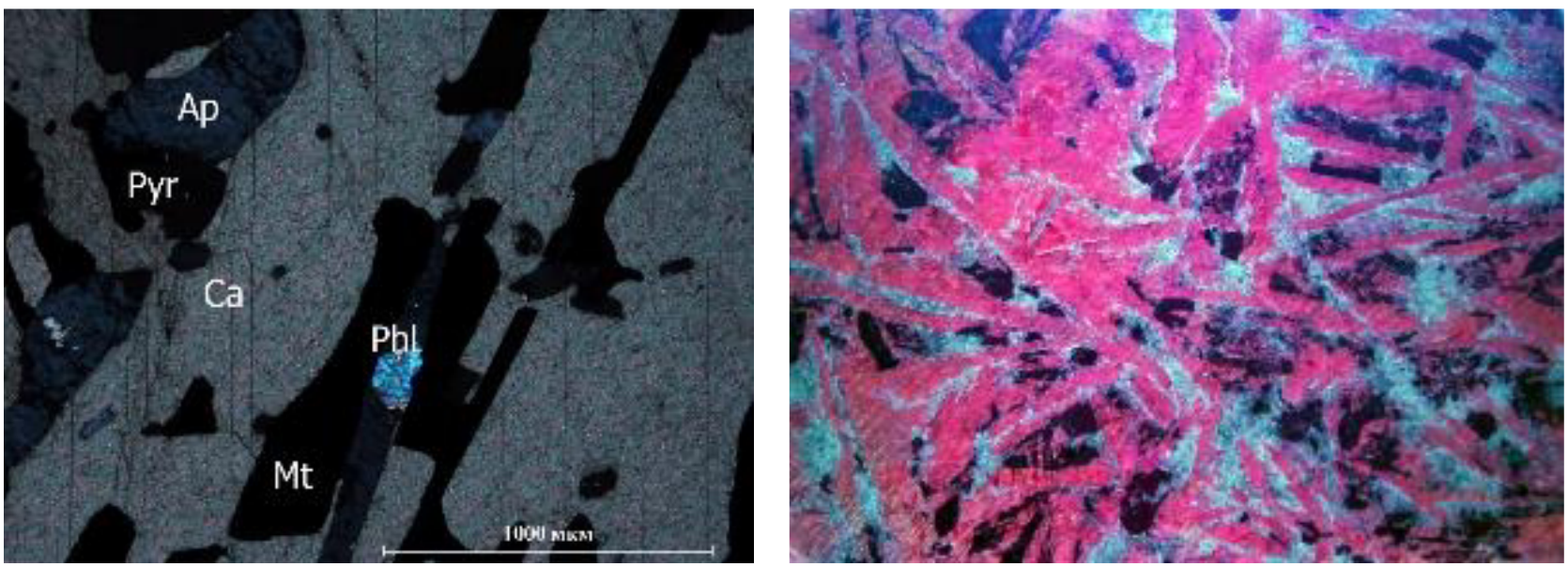

Puc. 4. Апатит-кальцитовый карбонатит с магнетитом и пирротином. Интерстициальные промежутки между индивидами кальцита заполнены скелетно-графическими агрегатами апатита и магнетита. Шлиф C25к/1b-31,1 (№ 2.19). Слева фото шлифа с анализатором; Справа - фото образца с применением УФ освещения. Здесь и далее: Руг - пирротин.

\section{Рядовые апатит-карбонатные руды}

Рядовые руды представлены преимущественно карбонатитами и флогопит-нефелино-пироксеновыми породами. В зависимости от преобладания тех или иных породообразующих минералов выделяются следующие разновидности карбонатитов (табл. 2): апатит-флогопитовые (рис. 5), апатит-кальцитовые с флогопитом (рис. 5) и апатит-кальцитовые. Рудные минералы представлены магнетитом и пирротином. Для пород типичны массивная и полосчатая текстуры и гипидиоморфнозернистая структура. По мере удаления от контакта флогопит-нефелин-пироксеновой породы и карбонатитов, в последних наблюдается увеличение содержания апатита до $10 \%$ и уменьшение количества флогопита с 15 до $1 \%$. Флогопит-нефелин-пироксеновая порода имеет сланцеватую текстуру и лепидогранобластовую структуру и характеризуется развитием кальцита и апатита в промежутках между породообразующими минералами (рис. 6).

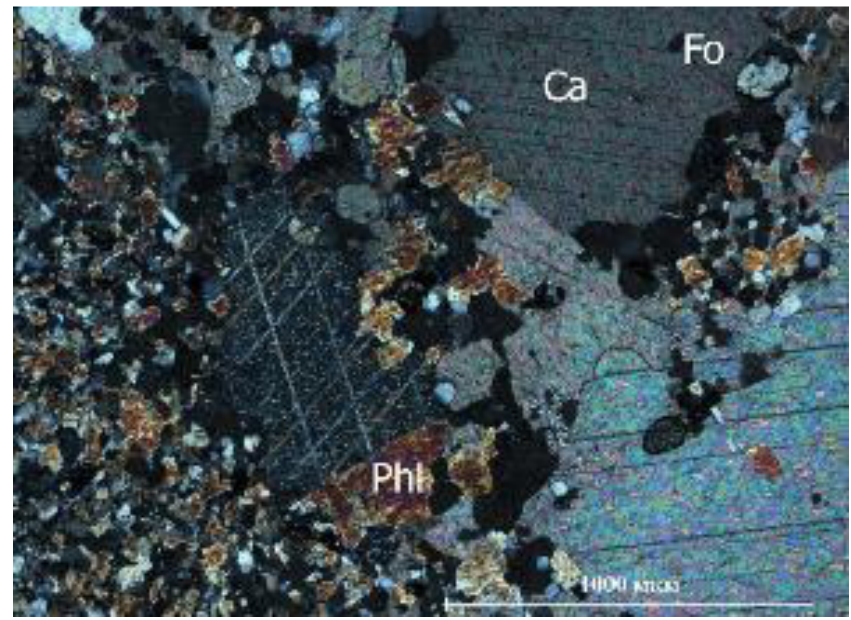

Невысокое содержание $\mathrm{P}_{2} \mathrm{O}_{5}$ обусловлено неравномерным распределением апатита в породах этого типа руд. Значительное содержание $\mathrm{MgO}$ в породах сопряжено с присутствием флогопита до 30 мас. \% (табл.4).

Таблица 2

Минеральный состав рядовых руд

\begin{tabular}{|l|c|c|c|}
\hline \multirow{2}{*}{ Минерал } & \multicolumn{3}{|c|}{ Содержания минералов, \% } \\
\cline { 2 - 4 } & $\begin{array}{c}\text { шлиф } \\
\text { С25/5c-145,2 } \\
\text { (№ 2.3) }\end{array}$ & $\begin{array}{c}\text { шлиф } \\
\text { С25к/5e-146,6 } \\
\text { (№ 2.8) }\end{array}$ & $\begin{array}{c}\text { шллиф } \\
\text { С25/5a-141,0 } \\
\text { (№ 2.11) }\end{array}$ \\
\hline Кальцит & 74 & 92 & ед. 3н. \\
\hline Апатит & 5 & 4 & ед. 3н. \\
\hline Флогопит & 20 & 3 & 28 \\
\hline Форстерит & 1 & - & - \\
\hline $\begin{array}{l}\text { Рудные } \\
\text { минералы }\end{array}$ & - & 1 & ед. зн. \\
\hline Авгит & - & - & 40 \\
\hline Нефелин & - & - & 32 \\
\hline Итого: & 100 & 100 & 100 \\
\hline
\end{tabular}

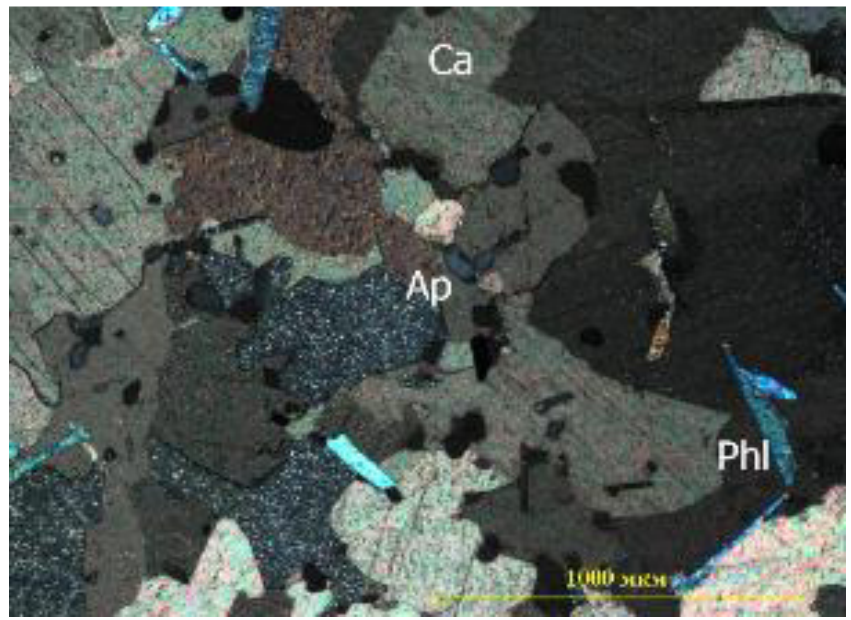

Puc. 5. Разновидности карбонатитов. Слева - апатит-флогопит-кальцитовый карбонатит с форстеритом. Шлиф С25к/5c145,2 (№ 2.3). Здесь и далее: Fo - форстерит; Справа - апатит-кальцитовый карбонатит с флогопитом. Шлиф С25к/5е-146,6 (№ 2.8). Фото шлифа с анализатором 


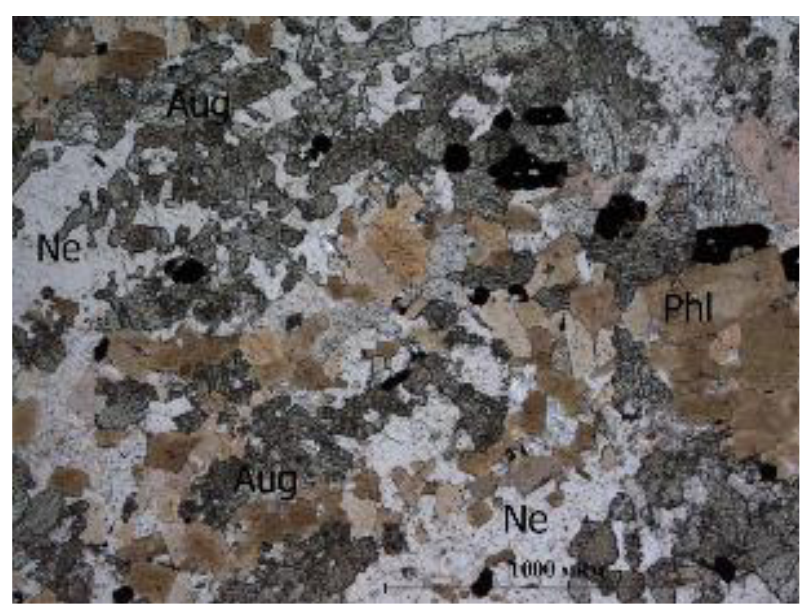

Рис. 6. Флогопит-нефелин-пироксеновая порода. Шлиф С25к/5a-141,0 (№ 2.11). Здесь и далее: Aug авгит, $\mathrm{Ne}$ - нефелин. Фото шлифа с анализатором.

\section{Бедные апатит-карбонатные руды}

Среди бедных руд преобладают карбонатиты и вмещающие их флогопит-нефелин-пироксеновые породы. По соотношению главных минералов карбонатиты подразделяются на кальцитовые, апатит-кальцитовые и флогопит-кальцитовые (рис. 7). Породы отличаются крупной зернистостью минералов, невысоким содержанием апатита и постоянным присутствием флогопита. Спорадически встречается тетраферрифлогопит. Рудные минералы неравномерно рассеяны в породах и представлены магнетитом и пирротином. Характерны гипидиоморфнозернистая и крупнозернистая структуры, полосчатая и массивная текстуры.

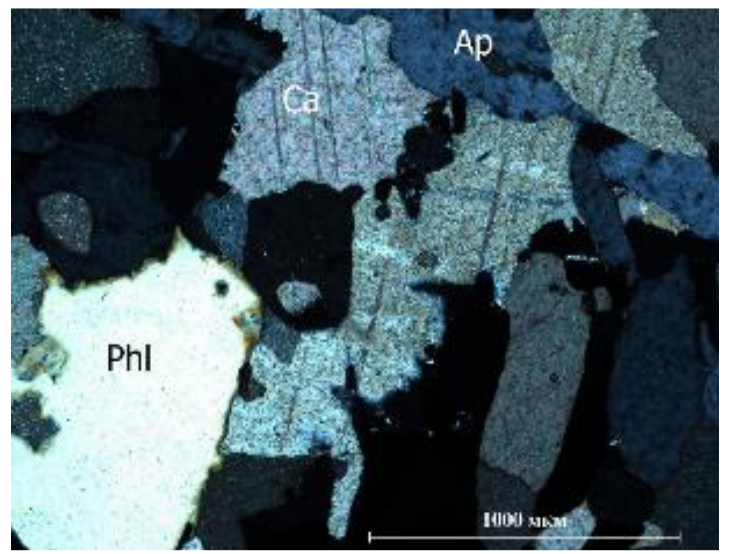

Таблица 3

Минеральный состав бедньх руд

\begin{tabular}{|l|c|c|c|}
\hline \multirow{2}{*}{ Минерал } & \multicolumn{3}{|c|}{ Содержания минералов, \% } \\
\cline { 2 - 4 } & $\begin{array}{c}\text { шлиф } \\
\text { С25к/2d- } \\
69,6 \\
\text { (№ 2.17) }\end{array}$ & $\begin{array}{c}\text { шлиф } \\
\text { С25к/6c- } \\
156,3 \\
\text { (№ 2.13) }\end{array}$ & $\begin{array}{c}\text { Ш25иф } \\
\text { С25g- } \\
\text { (№ 2.14) }\end{array}$ \\
\hline Авгит & - & 41 & - \\
\hline Нефелин & - & 30 & 15 \\
\hline Флогопит & 1 & 29 & 5 \\
\hline Альбит & - & - & 15 \\
\hline Эгирин-авгит & - & - & 27 \\
\hline $\begin{array}{l}\text { Калиево-натриевый } \\
\text { полевой шпат }\end{array}$ & - & - & 36 \\
\hline Хлорит & - & - & - \\
\hline Рудные минералы & - & - & - \\
\hline Кальцит & 96 & & \\
\hline Апатит & 3 & & \\
\hline \multicolumn{1}{|c|}{ Итого: } & 100 & 100 & 100 \\
\hline
\end{tabular}

Вмещающие породы отличаются разнообразным минеральным составом (табл. 3). Флогопит-нефелин-пироксеновая порода характеризуются присутствием магнетита, сланцеватой текстурой и лепидогранобластовой структурой (рис.7). Фениты - массивные флогопит-нефелин-полевошпатовые породы с гетеробластовой и гломеробластовой текстурой (рис. 8) и акцессорными минералами - кальцитом, апатитом и титанитом.

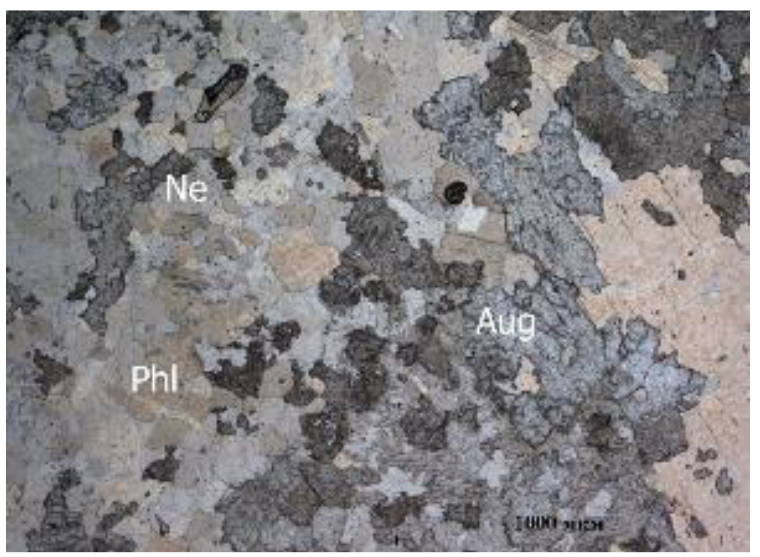

Рuc. 7. Разновидности бедных руд. Слева - кальцитовый карбонатит с апатитом. Фото шлифа с анализатором. Шлиф С25к/2d-69,6 (№ 2.17); Справа - флогопит-нефелин-пироксеновая порода. Фото шлифа без анализатора. Шлиф С25к/6с156,3 (№ 2.13)

Таблица 4

Средний взвешенный химический состав руд, масс. \%.

\begin{tabular}{|l|c|c|c|c|c|c|}
\hline \multicolumn{1}{|c|}{ Сорта руд } & $\mathrm{SiO}_{2}$ & $\mathrm{Fe}$ общ. & $\mathrm{MgO}$ & $\mathrm{CaO}$ & $\mathrm{P}_{2} \mathrm{O}_{5}$ & $\mathrm{SrO}$ \\
\hline Богатые & 1,61 & 5,05 & 3,3 & 50,84 & 3,18 & 0,65 \\
\hline Рядовые (карбонатиты) & 1,15 & 3,27 & 2,84 & 52,74 & 1,78 & 0,54 \\
\hline Рядовые (вмещающие) & 16,12 & 4,43 & 11,11 & 35,34 & 1,77 & 0,52 \\
\hline Бедные (карбонатиты) & 2,59 & 3,25 & 2,77 & 50,58 & 1,37 & 0,68 \\
\hline Бедные (вмещающие) & 38,08 & 6,49 & 7,80 & 14,78 & 1,10 & 0,22 \\
\hline
\end{tabular}



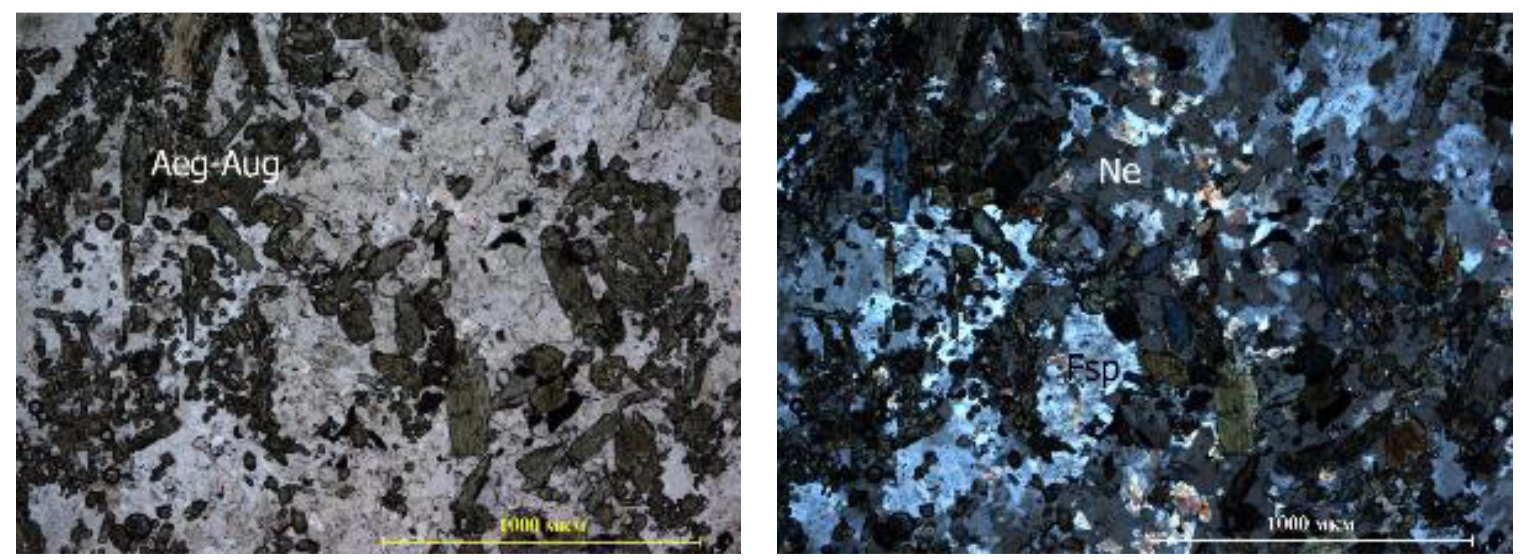

Puc. 8. Пироксен-нефелин-полевошпатовый фенит. Шлиф С25к/6g-178,0 (№2.14). Здесь и далее: Aeg-Aug - эгиринавгит, Fsp - калиево-натриевый полевой шпат; Слева - без анализатора, справа - с анализатором.

\section{Редкометалльная минерализация апатит-карбонатных руд}

Основными минералами кальцитовых карбонатитов являются кальцит и апатит. Меньше распространены флогопит, форстерит и магнетит. Редкие минералы представлены бадделеитом и пирохлором.

Бадделеит является характерным акцессорным минералом кальцитовых карбонатитов и потенциально представляет промышленный интерес $[9,10,11]$. Минерал образует призматические кристаллы, часто сдвойникованные, иногда индивиды неправильной формы (рис. 9, 10). Микрозондовыми исследованиями был определен состав бадделеита и произведен расчет кристаллохимических коэффициентов [12]. В состав бадделеита в качестве примеси входит гафний (от 0,73 до 1,72 мас. \%), в качестве микропримеси - стронций. Формула бадделеита с усредненными коэффициентами имеет следующий вид: $\left(\mathrm{Zr}_{0,99} \mathrm{Hf}_{0,01}\right) \mathrm{O}_{2}$.

В ассоциации с бадделеитом наблюдается пирохлор, который также является акцессорным минералом и образует редкие октаэдрические кристаллы (рис. 10). Он представлен уранпирохлором и содержит примеси (мас. \%) $\mathrm{UO}_{2}(<12,4 \%), \mathrm{Ta}_{2} \mathrm{O}_{5}(<5,2 \%)$, $\mathrm{ZrO}_{2}(<5,1 \%)$ (табл. 1); кроме того, в небольших количествах присутствуют $\mathrm{Fe}_{2} \mathrm{O}_{3}, \mathrm{TiO}_{2}, \mathrm{Ce}_{2} \mathrm{O}_{3}$ и $\mathrm{SrO}$. Уранпирохлор характеризуется следующей усредненной формулой: $\left(\mathrm{Ca}_{1,07}, \mathrm{Na}_{0,62}, \mathrm{Sr}_{0,02}, \mathrm{Ce}_{0,03}, \mathrm{U}_{0,19}\right)_{1,92}$ $\left(\mathrm{Nb}_{1,62}, \mathrm{Ta}_{0,09}, \mathrm{Ti}_{0,04}, \mathrm{Zr}_{0,17}, \mathrm{Fe}_{0,09}\right)_{2} \mathrm{O}_{6}\left(\mathrm{OH}_{0,8}, \mathrm{~F}_{0,2}\right)_{1}$.
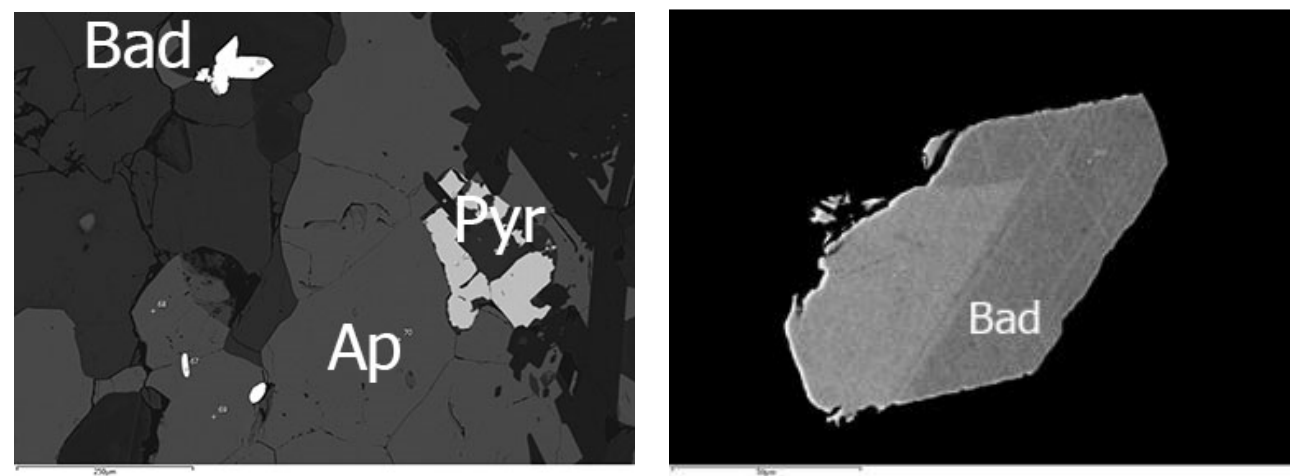

Puc.9. Призматические кристаллы бадделеита. Здесь и далее: Bad - бадделеит. Изображение BSE.
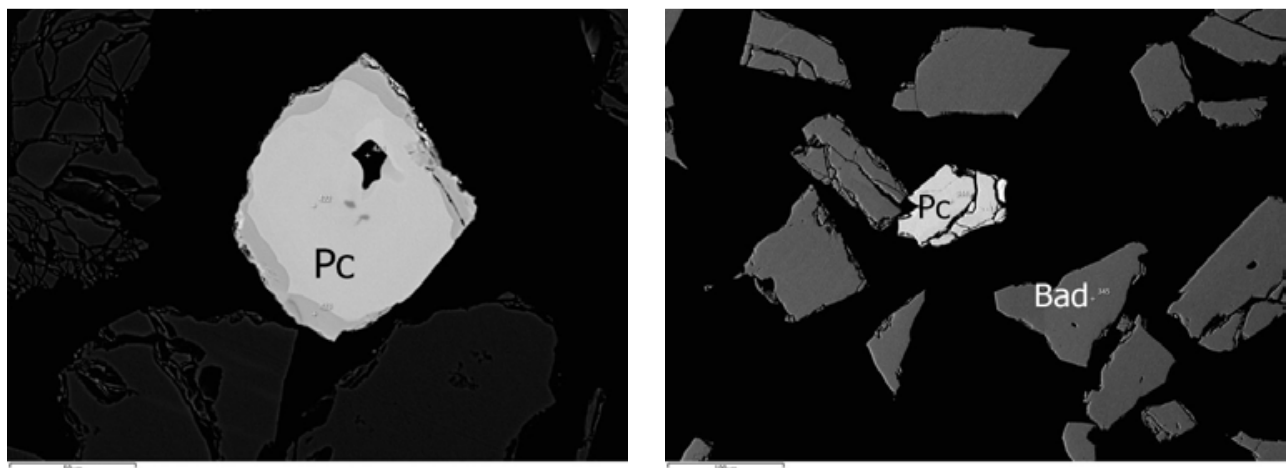

Puc.10. Октаэдрические кристаллы пирохлора. Здесь и далее: Рc - пирохлор. Изображение BSE. 


\section{Заключение}

Изучение вещественного состава кальцитовых карбонатитов Ковдорского массива позволило сделать следующие выводы.

Апатит-карбонатные руды подразделяются на следующие технологические сорта: богатые $\left(\mathrm{P}_{2} \mathrm{O}_{5}>3\right.$ мас. \%), рядовые $\left(\mathrm{P}_{2} \mathrm{O}_{5} 3-1,5\right.$ мас. \%) и бедные $\left(\mathrm{P}_{2} \mathrm{O}_{5}\right.$ $<1,5$ мас. \%). Руды отчетливо разделяются по текстурно-структурным характеристикам и морфологическим особенностям минеральных зерен, Среди богатых апатит-карбонатные руд преобладают лейстовые апатит-кальцитовые карбонатиты, рядовые представлены преимущественно разнозернистыми апатитсодержащими кальцитовыми карбонатитами с флогопитом, бедные - крупнозернистыми апатитсодержащими карбонатитами и вмещающими породами. Формы нахождения, текстурно-структурные особенности и ассоциации минералов исследуемых руд являются характерными для апатит-карбонатного месторождения Ковдорского массива. Предложенная типизация руд может быть учтена при разработке схем их обогащения.

\section{ЛИТЕРАТУРА}

1. Афанасьев, Б. В. Минеральные ресурсы щелочно-ультраосновных массивов Кольского полуострова / Б. В. Афанасьев ; СПб : Изд-во «Роза ветров» - 2011 г. - 224 с.

2. Геология рудных районов Мурманской области / В. И Пожиленко [и др.] ; отв. ред. В. И. Пожиленко. - Апатиты : Изд. Кольского научного центра РАН, 2002 г. - 359 с.

3. Римская-Корсакова, О. М. Геология месторождений Ковдорского массива / О.М.Римская-Корсакова, Н. И. Краснова, СПб. : Изд-во СПбГУ, 2002 г. - 146 с.

\section{Санкт-Петербургский горный университет}

Степанова Ксения Дмитриевна, аспирант кафедры геологии и разведки месторождений полезных ископаемых E-mail: geologicalmind@yandex.ru

Санкт-Петербургский государственный университет

Петров Сергей Викторович, доцент кафедры геологии месторождений полезных ископаемых, кандидат геологоминералогических наук

E-mail: s.petrov@spbu.ru

Тел.: +7 (812) 363-61-95
4. Ресурсный потенциал Кольской редкоземельной провинции. Геология и стратегические полезные ископаемые Кольского региона / Коноплёва Н. Г. [и др.] // Труды IX Всероссийской Ферсмановской научной сессии, посвященной 60-летию Геологического института КНЦ РАН. (Апатиты, 2-3 апреля 2012 г.). - Апатиты. - С. 266-270.

5. Krasnova, N. I. Kovdor - classic phoscorites and carbonatites / N. I. Krasnova, E. G. Balaganskaya, D. Garcia // Mineralogical Society Series. Mineralog. Soc. London. - 2004. Vol. 10. - P. 99-132.

6. Новые данные о редкоземельном потенциале Мурманской области / А. В. Базай [и др.] // Вестник Кольского научного центра РАН. - 2014. - № 4. - С. 50-65.

7. Особенности инженерно-геологического изучения массивов скальных пород в целях проектирования глубоких карьеров на примере Ковдорского месторождения магнетитовых апатитовых руд. Часть 1 / Д. В. Мелихов [и др.] // Вестник Кольского научного центра РАН. - 2016. - № 1. C. $15-25$.

8. Zaitsev, A. N. Rare-earth elements minerals in carbonites of the Kola Alkaline province (northern Fennoscandia) / A. N. Zaitsev, F. Wall, A. R. Chakhmouradian // 1st European Rare Earth Resources Conference (Milos, 07.09.2014).- Greece.- P. 343-347

9. Wall, F. Rare earth minerals in Kola carbonatites / F. Wall, A. N. Zaitsev // Mineralogical Society Series. Mineralog. Soc. London. - 2004. - Vol. 10. -P. 341-369.

10. Иванюк, Г. Ю. Минералы Ковдора / Г. Ю. Иванюк, В. Н. Яковенчук; Апатиты : Изд-во Кольского НЦ РАН. - 1997 г. $-116 \mathrm{c}$.

11. Petrov, S. V. Economic deposits associated with the alkaline and ultrabasic complexes of the Kola Peninsula. / S. V. Petrov // Mineralogical Society Series. Mineralog. Soc. London. - 2004. - Vol. 10. - P. 469--490.

12. Буллах, А. Г. Структура, изоморфизм, формулы, классификация минералов / А. Г. Булах, А. А. Золотарев, В. Г. Кривовичев ; СПб. : Изд-во С.-Петерб. ун-та, 2014 г. - 133 с.

\section{Saint-Petersburg Mining University}

Stepanova K. D., postgraduate student of the Department of Geology and Mineral Deposits Prospecting

E-mail: geologicalmind@yandex.ru

Saint-Petersburg State University

Petrov S. V., Associate Professor of the Department of Geology of Mineral Deposits, Candidate of Geological and Mineralogical Sciences

E-mail: s.petrov@spbu.ru

Tel.: +7 (812) 363-61-95 